当科における血縁ドナー選定過程についての後方視的検討

五井理恵 ${ }^{1,2}$, 梅田雄嗣 ${ }^{1}$, 川口晃司 ${ }^{1}$, 岩井 篤 $^{1}$, 三上真充 ${ }^{1}$, 納富誠司郎 ${ }^{1}$, 才田 聡 $^{1}$, 平松英文 ${ }^{1}$, 平家俊男 ${ }^{1}$, 足立壯一 ${ }^{3}$

1京都大学医学部附属病院小児科

2京都大学医学部附属病院輸血細胞治療部

3 京都大学大学院医学研究科人間健康科学

1995年から 2015 年の間に当科で血縁ドナーを第一候補として計画された造血幹細胞移植について HLA 検查の実施 状況, 最終的なドナー選択, 第一候補ドナーから移植しなかった症例の経緯, 臨床経過を後方視的に検討した。対象 59 件の内訳は同胞 35 件, 親 24 件で, 54 件が最終的にドナーとなった。一方, 第一候補ドナー 5 件（同胞 4 件, 親 1 件）のうち 4 件はドナーの健康上の問題, ドナー本人または家族の希望, 遺伝性疾患のキャリアからの移植の回避 などの理由で代替ドナーに変更となり， 1 件は患者の希望により移植が中止されたため, 最終的に採取が施行されな かった。さらに, 2 件のドナー候補は健康上の理由で骨髄から末梢血幹細胞採取に変更となった。ドナー候補への不 必要な苦痛を避けるため, HLA 検索前に年齢に応じた身体的・精神的適格性の判定とドナー候補・家族へのイン フォームド・コンセントを十分に行う必要があると考えられた。（日本造血細胞移植学会誌５(3): 82-86, 2016. )

\section{緒言}

造血幹細胞移植は白血病・悪性リンパ腫などの血液悪性 疾患や再生不良性貧血・遺伝性疾患の根治治療として有力 な治療選択肢である。家族内で HLA 完全一致または 1 座 不一致の適合ドナーが得られる確率は $1 / 4$ 程度である。血 縁者適合ドナーがいない場合も, 骨髄バンク・臍带血バン クから得られたドナーからの非血縁者間移植が施行できれ ば血縁者間移植と遜色ない治療成績が期待できることが報 告されている 1 。一方, 近年の移植技術の進歩により HLA 2 座以上不一致の血縁ドナーからの造血幹細胞移植も比較的 安全に施行できるようになり ${ }^{2}$, 血縁ドナーの必要性は依 然として高い。

健常ドナーからの造血幹細胞移植法には骨髄移植と末梢 血幹細胞移植があるが, 前者は全身麻酔下における骨髄採 取, 後者は G-CSF などのサイトカイン投与やブラッドアク セスに伴う重篤な有害事象が $0.1 \sim 1.0 \%$ 程度起こり得るリ スクのある医療行為である 3,4 。そのため, 非血縁ドナーの 場合はドナーおよび患者両方の安全を最優先し, 調整医 師・コーディネーターによる厳正な適格性判定と十分なイ ンフォームド・コンセントが行われている。一方, 血縁ド ナーが第一候補となった場合は患者の救命が最優先され,
ドナーの安全性や特に小児ドナーに対する説明・意志確認 などへの配慮は不十分な事がある 5 。

今回，われわれは当科で行われた造血幹細胞移植におけ るドナー選定過程と臨床経過を振り返り，特に血縁ドナー として選定されながら方針を変更した症例を検討したので 報告する。

\section{材料および方法}

1995 年から 2015 年の間に当科で血縁ドナーからの造血 幹細胞移植を計画した 59 件 (57 例)について患者とドナー の背景, HLA 検査の実施状況, 最終的なドナー選択, 第一 候補ドナーから移植しなかった症例の経緯, 臨床経過を後 方視的に検討した。ドナーへの説明はレシピエントの担当 医とは異なる小监科ドナー外来担当医師が行い, 移植コー ディネーターが随時説明を補足した。説明に同意が得られ た場合は，本人または代諾者から書面で同意を取得した。 骨髄および末梢血幹細胞ドナーの適格性は, 日本骨䯣バン クの「ドナー適格性判定基準」7に則り, 移植コーディネー ターの立ち会いのもと小児科ドナー外来担当医師, 血液腫 瘍内科医師, 輸血部医師からなる院内のドナー判定委員会 で判定した。また，日本小览血液・がん学会の「健常小児

Submitted December 12, 2015; Accepted January 24, 2016. (Handling Editor: Akio Kohno, Konan Kosei Hospital)

Key words: allogeneic hematopoietic stem cell transplantation, related donor, eligibility, pediatric, informed consent

Correspondence: Katsutsugu Umeda 54 Kawahara-cho, Shogoin, Sakyou-ku, Kyoto, 606-8507, Japan. E-mail: umeume@kuhp.kyoto-u. ac.jp

dx.doi.org/10.7889/hct. 5.82 (C) The Japan Society for Hematopoietic Cell Transplantation. 
Table1. Characteristics of recipient and donor

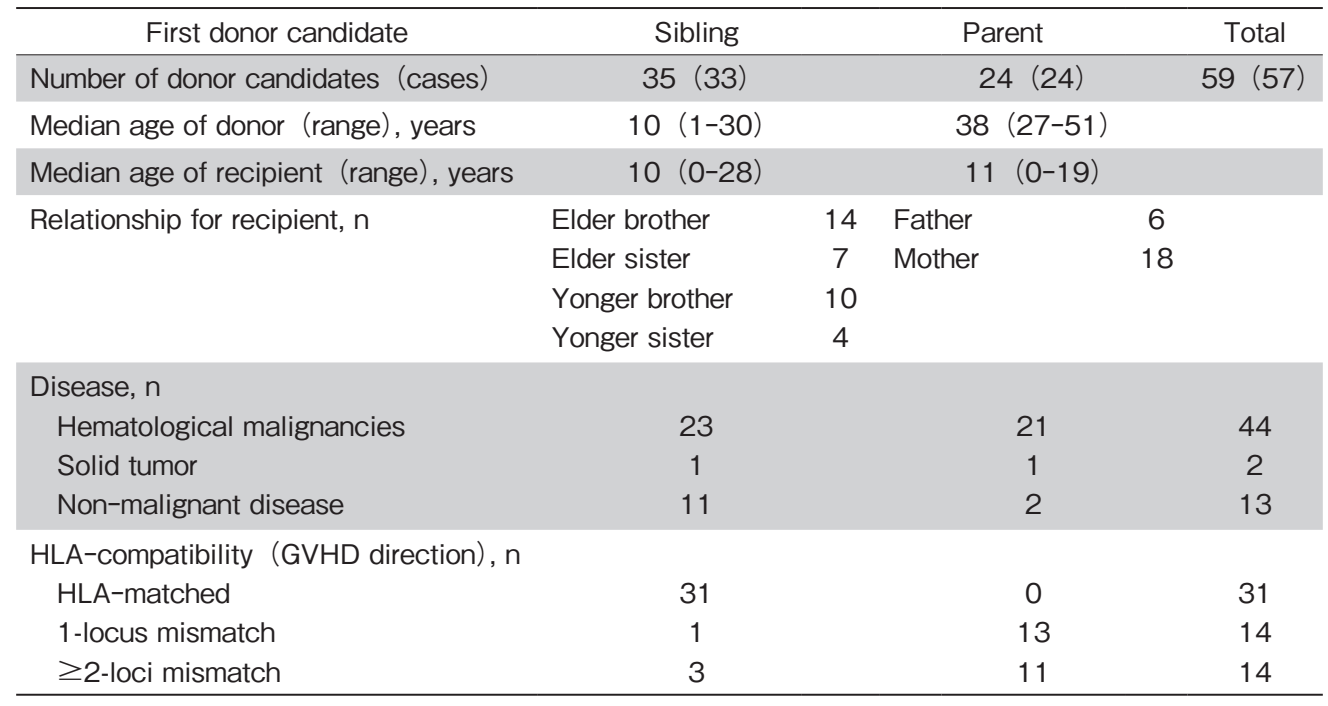

Table2. Final decision for transplantation

\begin{tabular}{|c|c|c|c|}
\hline First donor candidate & Sibling & Parent & Total \\
\hline Number of donor candidates & 35 & 24 & 59 \\
\hline $\begin{array}{l}\text { Number of transplants from the first donor } \\
\text { candidate, } \mathrm{n}(\%)\end{array}$ & $31(88.6 \%)$ & $23(95.8 \%)$ & $54(91.5 \%)$ \\
\hline \multicolumn{4}{|l|}{ Stem cell source, $\mathrm{n}(\%)$} \\
\hline Bone marrow & $24(77.4 \%)$ & $10(43.5 \%)$ & $34(63.0 \%)$ \\
\hline Peripheral blood stem cell & $6(19.4 \%)$ & $13(56.5 \%)$ & $19(35.2 \%)$ \\
\hline Bone marrow + cord blood & $1(3.2 \%)$ & $0(0 \%)$ & $1(1.8 \%)$ \\
\hline $\begin{array}{l}\text { Number of cases who did not undergo } \\
\text { transplants from the first donor candidate, } \mathrm{n}(\%)\end{array}$ & $4(11.4 \%)$ & $1(4.2 \%)$ & $5(8.5 \%)$ \\
\hline Switch to alternative donor & 3 & 1 & 4 \\
\hline Discontinuance of transplantation & 1 & 0 & 1 \\
\hline
\end{tabular}

ドナーからの造血幹細胞採取に関する倫理指針」8に従い, ドナー年齢の下限は骨髄採取 1 歳, 末梢血幹細胞採取 10 歳 とした。HLA 一致度は HLA-A，-B, -DRの 6 座を対象と して GVHD 方向のみの血清型不適合数を数えた。

\section{結果}

\section{1. 患者とドナーの背景（Table 1)}

対象は 59 件で, うち同胞 35 件（年齢：1～30 歳, 中央 值 10 歳), 親 24 件 (年齢: 27〜 51 歳, 中央值 38 歳) で あった。疾患の内訳は血液悪性疾患 44 件, 固形腫瘍 2 件, 非悪性疾患 13 件であった。第一候補となった血縁ドナーの HLA 一致度（GVHD 方向）は同胞ドナーでは完全一致 31 件, 1 座不一致 1 件, 2 座以上不一致 3 件と大半が完全一致 であったが，親ドナーでは 1 座不一致 13 件， 2 座以上不一 致 11 件であった。

\section{2. 最終的なドナー選択（Table 2)}

59 例中 54 例 $(91.5 \%)$ が最終的にドナーとなり，骨髄移 植 34 件, 末梢血幹細胞移植 19 件, 骨髄 + 臍帯血移植 1 件 が施行された。骨髄採取は同胞ドナーの $80.6 \%$, 親ドナー の $43.5 \%$ に施行された。骨髄十臍帯血移植を施行した症例 は再生不良性貧血の 6 歳男児で，出産時に保存した臍帯血 の HLA 検査で妹が HLA 完全一致と判明したが有核細胞数 が $2.0 \times 10^{7}$ 個 $/ \mathrm{kg}$ と若干少なかったため, 1 歳時に $240 \mathrm{~mL}$ の自己血を準備して $210 \mathrm{~mL}(20 \mathrm{~mL} / \mathrm{kg}$, 有核細胞数 $1.35 \times$ $10^{8}$ 個 $/ \mathrm{kg}$ ）の骨䯣を採取し，保存していた臍帯血と一緒に 患者に輸注した ${ }^{9}$ 。骨髄採取, 未梢血幹細胞採取を行った全 件において重篤な有害事象は認めなかった。

最終的に第一ドナー候補から移植しなかった症例は 5 件 $(8.5 \%)$ で, 同胞ドナー 4 件 $(11.4 \%)$, 親ドナー 1 件 $(4.2 \%)$ であった。なお, 同胞ドナー 1 件 (気管支喘息), 親ドナー 1 件（腰椎ヘルニア）は健康上の理由で骨髄から末梢血幹 細胞採取に変更となった。 
Table3. Clinical details of 5 patients who did not undergo transplantation from the first donor candidate

\begin{tabular}{cccccccc}
\hline $\begin{array}{c}\text { Patient } \\
\text { No. }\end{array}$ & Gender & $\begin{array}{c}\text { Age at } \\
\text { HSCT (year) }\end{array}$ & Disease & $\begin{array}{c}\text { Relationship and age of } \\
\text { the first donor candidate }\end{array}$ & $\begin{array}{c}\text { Alternative } \\
\text { donor source }\end{array}$ & $\begin{array}{c}\text { Cause of } \\
\text { donor change }\end{array}$ & Outcome \\
\hline 1 & M & 11 & AML & Yonger brother/7 & Cord blood & Bronchial asthma & DOO \\
2 & F & 0 & ALL & Elder brother/2 & Cord blood & Intention of the family & DOD \\
3 & F & 6 & ALL & Elder brother/2 & $\begin{array}{c}\text { Bone marrow } \\
\text { (Father) }\end{array}$ & Intention of the donor & $\begin{array}{c}\text { NED (following } \\
\text { retransplantation) }\end{array}$ \\
4 & M & 8 & ALD & Mother/36 & Cord blood & Carrier of the disease & NED \\
5 & F & 15 & NHL & Yonger brother/7 & None & Intention of the patient & NED \\
\hline
\end{tabular}

M, male; F, female; HSCT, hematopoietic stem cell transplantation; AML, acute myeloid leukemia; ALL, acute lymphoid leukemia; ALD, adrenoleukodystrophy; NHL, non-Hodgkin Iymphoma; DOO, dead of other causes; DOD, dead of disease; NED no evidence of disease.

3. 第一候補ドナーから移植しなかった症例の経緯（Table 3) 最終的に第一ドナー候補から移植しなかった 5 件のうち 4 件は代替ドナーからの移植に変更となったが，その内訳 は非血縁臍带血 3 件，他の血縁ドナー 1 件であった。患者 1 は同胞ドナーの健康上の問題（気管支喘息）より，小児 アレルギー専門医の意見を参考にドナー判定委員会が不適 格と判定した。患者 2 は同胞ドナーが 2 歳と幼少なため, 家族の希望により臍帯血移植に変更した。患者 3 は急性り ンパ性白血病の女児で, HLA 完全一致の兄は手術に対する 恐怖心が強い事から不適格と判断し，第 2 宽解期に 1 座不 一致の父から骨䯣移植を施行した。症例 4 は第一候補ド ナーが遺伝性疾患のキャリアであることが判明し，不適格 と判定した。症例 5 は患者本人の希望により移植が中止さ れ，化学療法と放射線照射を継続する方針になった。 5 件 の転帚は無病生存中 3 件, 原病死 1 件, 合併症死 1 件であっ た。

\section{考察}

今回の検討では, HLA 検査結果で第一ドナー候補にあげ られた血縁者の $8.5 \%$ が様々な理由で最終的な移植ドナー にならなかった。当科では2005年にドナー選定過程を倫理 的視点から見直し, HLA 検査を行う前にドナーの身体的・ 精神的適格性を十分に行うことを徹底することになった。 その結果，第一候補ドナーから移植しない方針はすべて 2005 年以降に決定されており, それ以前は十分な血縁ド ナーの身体的・精神的適格性判定が実施されていなかった 可能性が考えられた。

海外の報告では非血縁成人ドナーの $8.8 \%$ が骨髄または 末梢血幹細胞採取について健康上不適格と判定され，その 理由としては皮膚疾患, 内分泌疾患, 血液・凝固疾患が上 位を占めていた ${ }^{10}$ 。一方，小児ドナーに対する身体的適格 性についての報告はないが，われわれの検討では気管支喘 息のため 1 例は代替ドナーに変更となり，もう 1 例は骨髄
から末梢血幹細胞採取に変更となった。さらに，小児ド ナーの場合はレシピエントの体重差があまりにも大きく， 十分な自己血を準備していても日本骨髄バンクの「骨髄採 取マニュアル $ل^{11}$ で定められた採取量では不十分である ケースも想定される。このような場合には過剩な骨髄採取 や同種輸血は当然避けるべきであり ${ }^{5,6}$, 代替ドナーからの 移植も考慮する必要がある。また，小児期に造血幹細胞移 植の適応となる事が多い遺伝性疾患のキャリアは疾患毎に ドナーとしての適格性が異なるため, 迅速な保因者診断と 適切な遺伝カウンセリングを含めた入念なドナー検索が必 要となる。以上より，小児ドナー候補に扔ける身体的適格 性については, 非血縁ドナーの判定基準に加えて小児特有 の背景も考虑した検討が必要と考えられた。

今回の検討ではドナー本人または家族の希望により 3 人 の HLA 一致同胞ドナー候補からの骨髄採取が中止となり, 家族の希望により 2 例の同胞ドナー候補の HLA 検査が実 施されなかった。骨髄採取，末梢血幹細胞採取はいずれも 安全性の確立した採取法であるが，ドナーに無償の身体 的・精神的負担を求めることによる心理社会的な影響は看 過できない6,12。一方，ドナーにならなかった同胞にも疎外 感・絶望など多大な精神的影響を及ぼすことも報告されて いる ${ }^{13}$ 。そのため, 非血縁ドナーの場合は本人だけでなく 配偶者や親権者などの近親者の同意の確認が必須となって いるが，小児ドナーの場合は自己決定権が保障されず，本 人の同意が未確認なまま採取計画が進行する場合も多い。 また，両親は患者の方に関心が向きやすいため，同胞ド ナーの代理人として不十分である可能性も指摘されてい る5 。さらに, 10 歳未満のドナー場合は本人に対する説明・ 同意のプロセスを経ること自体が困難であり，日本小児血 液・がん学会の「健常小児ドナーからの造血幹細胞採取に 関する倫理指針」8では適格性が認められているものの，両 親の同意のみでドナーとして選定される倫理的問題が残 る。以上より，HLA 検查を行う前に採取に関連した倫理的 問題点を両親に十分に説明して同胞の杵利擁護に努める共 
に，年齢に応じた同胞ドナー自身へ十分なインフォーム ド・コンセントを行う必要があると考えられた。

第一ドナー候補から移植しなかった症例の中には，患 者・ドナー・家族の意思に沿う結果として代替ドナーから の移植を選択したケース（患者3）や移植以外の治療を選 択したケース（患者 5) が認められた。また, これら 2 件 を含めて第一ドナー候補から移植しなかった 5 件中 3 件が 無病生存中であった。そのため, 複数の治療選択肢が考え られる患者に対しては各治療法の治療成績や合併症などを 十分説明し, HLA 検索を進める前に移植を受けることにつ いてしっかりとした同意を得ておく必要があると考えられ た。

今回，血縁ドナーからの造血幹細胞移植を計画した症例 のドナー選定過程を解析し，身体的または精神的に不適格 なドナー候補が HLA 検査を受けていたことが明らかに なった。ドナー候補への不要な負担をできる限り減らすた め, 医師・看護師・コーディネーター・心理士・ソーシャ ルワーカーなどの多職種の綿密な連携による十分なドナー 適格性の検討が必要不可欠と考えられた。

\section{著者役割}

五井理恵と梅田雄嗣がデータの解析および論文執筆を行っ た。五井理恵と川口晃司が図表の作成を行った。岩井篤, 三上 真充, 納富誠司郎, 才田聡, 平松英文がデー夕の収集および本 研究内容の科学的助言を行った。梅田雄嗣, 平家俊男, 足立壯 一が研究を統括した。

\section{利益相反の開示}

本研究において, 開示すべき利益相反は存在しない。

\section{参考文献}

1. Oliansky DM, Camitta B, Gaynon P, et al. Role of cytotoxic therapy with hematopoietic stem cell transplantation in the treatment of pediatric acute lymphoblastic leukemia: update of the evidence-based review. Biol Blood Marrow Transplant. 2012; 18: 505-522.

2. 杉田純一, 小杉端葉, 豊嶋崇徳. 移植後シクロフォス ファミドを用いたHLA 半合致移植の現状と課題. 日本造 血細胞移植学会雑誌. $2015 ; 4$ ：9-22.

3. Halter J, Kodera J, Adamson J, et al. Severe events in donors after allogeneic hematopoietic stem cell donation. Haematologica. 2009; 94: 94-101.

4. McCullough J, Kahl J, Adamson J, et al. Hematopoietic growth factors-use in normal blood and stem cell donors. Transfusion. 2008; 48: 2008-2025.

5. Chan KW, Gajewski JL, Supkins D Jr, et al. Use of minors as bone marrow donors: current attitude and management. A survey of 56 pediatric transplantaion centers. J Pediatr. 1996; 128: 644-648.

6. van Walraven SM, Straathof LM, Switzer et al. Immediate and long-term somatic effects, and health-related quality of life of BM donation during early childhood. A single-center report in 210 pediatric donors. Bone Marrow Transplant. 2013; 48: 4045.

7.「ドナー適格性判定基準」日本骨髄バンク 2014 年 9 月 15 日第二版.

8.「健常小児ドナーからの造血幹細胞採取の関する倫理指 針」. 日本小児血液・がん学会 造血幹細胞委員会 2002 年 4 月 20 日.

9. Umeda K, Adachi S, Wakanabe K, et al. Successful hematopoietic stem cell transplantation for aplastic anemia following living-related liver transplantation. Bone Marrow Transplant. 2002; 30: 531-534.

10. Bräuninger S, Thorausch K, Luxembourg B, et al. Deferral of volunteer stem cell donors referred for evaluation for matchedunrelated stem cell donation. Bone Marrow Transplant. 2014; 49: 1419 .

11.「骨髄採取マニュアル」. 日本骨髄バンク ドナー安全委 員会 2011 年 4 月 1 日第四版.

12. Shama WI. The experience and preparation of pediatric sibling bone marrow donors. Soc Work Health Care. 1998; 27: 89-99.

13. Packman WL. Psychosocial impact on pediatric BMT on sibling. Bone Marrow Transplant. 1999; 24: 701-706. 


\title{
Retrospective analysis of the related donor selection process: a single-institution experience
}

Rie Goi ${ }^{1,2}$, Katsutsugu Umeda ${ }^{1}$, Koji Kawaguchi ${ }^{1}$, Atsushi Iwai ${ }^{1}$, Masamitsu Mikami ${ }^{1}$, Seishiro Noudomi ${ }^{1}$, Satoshi Saida $^{1}$, Hidefumi Hiramatsu ${ }^{1}$, Toshio Heike ${ }^{1}$ and Souichi Adachi ${ }^{3}$

${ }^{1}$ Department of Pediatrics, Kyoto University Hospital

${ }^{2}$ Department of Transfusion Medicine and Cell Therapy, Kyoto University Hospital

${ }^{3}$ Human Health Sciences, Graduate School of Medicine, Kyoto University

\begin{abstract}
We retrospectively analyzed the arrangement of human leukocyte antigen (HLA) testing, the final decision about donation, and the clinical outcome of allogeneic hematopoietic stem cell transplantation (HSCT), which was planned to be performed from a related donor as the first candidate between 1995 and 2015 in our hospital. Of fifty-nine candidates (35 siblings and 24 parents), 54 were eventually selected as HSCT donors. However, HSCT was not performed from four siblings $(11.4 \%)$ and one parents $(4.2 \%)$. Four candidates were replaced by alternative donors due to the donor health problems, intention of the donors or their family members, or to avoid HSCT from a carrier of a congenital disease. HSCT from the other candidate was canceled because the patient did not consent to HSCT. Peripheral blood stem cell harvesting was performed instead of bone marrow harvesting in two other donors due to their health problems. The physical and psychological eligibility of donor candidates, appropriate for their age, should be sufficiently examined. Furthermore, informed consent should be obtained from pediatric donor candidates and their family before HLA testing to avoid the unnecessary pain. (Journal of Hematopoietic Cell Transplantation $5(3)$ : 82-86, 2016.)
\end{abstract}

